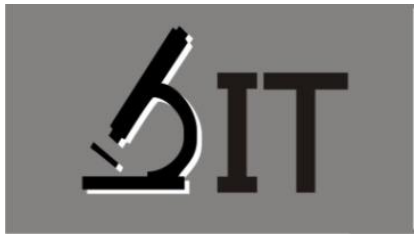

p-ISSN : 2597-8977

e-ISSN : $2597-8985$

Nanda Alwardah*)

Universitas Negeri Medan

Kardinal Sitorus

Universitas Negeri Medan

Nuraini

SMP Negeri 1 Kualuh Selatan
JIT 4 (2) (2021) 53-62

JURNAL IPA TERPADU

http://ojs.unm.ac.id/index.php/ipaterpadu

\section{PENERAPAN MODEL PEMBELAJARAN PROBLEM BASED LEARNING (PBL) MENGGUNAKAN MEDIA POWER POINT INTERAKTIF TERHADAP HASIL BELAJAR PESERTA DIDIK}

Abstrak: Penelitian ini bertujuan untuk melihat peningkatan hasil belajar IPA kelas VII SMP dengan menerapkan model Problem Based Learning (PBL) dengan menggunakan media power point interaktif. Jenis penelitian ini adalah penelitian tindakan kelas (PTK). Sampel penelitian terdiri dari 30 orang peserta didik. Instrumen berupa tes dalam bentuk pilihan berganda sebanyak 30 soal dengan 4 pilihan dan urian sebanyak 10 soal pada materi pencemaran lingkungan. Pembelajaran dilakukan dengan dua siklus serta setiap pembelajaran dilakukan pre-test dan post-test. Peningkatan presentasi N-Gain pada siklus I: 63,8\% (kategori sedang) dan siklus II: 81,2\% (kategori tinggi). Berdasarkan hasil penelitian dapat disimpulkan bahwa terdapat peningkatan hasil belajar IPA peserta didik SMP dengan menerapkan model PBL dengan menggunakan media power point interaktif pada materi Pencemaran lingkungan.

Kata Kunci: Problem Based Learning, Power Point Interaktif, Hasil Belajar, Pencemaran Lingkungan.

Abstract: The research aims to see an improvement in the results of studying the VII class science class with the application of the Problem Based Learning model using interactive power point. This kind of research is class action research. This research sample is 30 students. The instrument that used on this research is the form of multiple of 30 problems with 4 choices selections and urian of 10 problems on environmental pollution. The learning do with two cycles and every learning, doing pre-test and post-test. Percentage increase $\mathrm{N}$-Gain in the result of learning on cycle I: $63.8 \%$ (moderate) and cycle II: $81.2 \%$ (high). Research suggests that there has been an improvement in middle-school science studies by applying the Problem Based Learning model by using interactive power point on environmental pollution displacement.

Keyword: Problem Based Learning, Interactive Power Point, Learning Outcomes, Environmental Pollution.

*) Correspondence Author: nandaalwaardah@gmail.com. 


\section{PENDAHULUAN}

Pada era digital abad 21, perkembangan IPTEK semakin pesat dan maju yang mengharuskan sumber daya manusia (SDM) dapat mensinergikan dan mengintegrasikan antara kognitif dan skill sehingga menjadi manusia yang mampu beradaptasi dan berkompetisi. Pendidikan merupakan salah satu faktor yang penting untuk dapat menghasilkan sumber daya manusia yang berkompeten. Melalui pendidikan yang baik, diperoleh hal-hal baru sehingga dapat digunakan untuk menciptakan sumber daya manusia yang berkualitas. Ciri Pendidikan yang berkualitas harus mampu mencapai tujuan pendidikan. Tujuan pendidikan Indonesia tercantum dalam Undangundang RI Tahun 2003 tentang sistem pendidikan nasional yang menyebutkan bahwa: "pendidikan nasional berfungsi mengembangkan kemampuan dan membentuk watak serta peradaban bangsa yang bertujuan untuk mengembangkan potensi yang dimiliki peserta didik agar menjadi manusia yang berkualitas dengan ciri-ciri beriman bertakwa kepada Tuhan Yang Maha Esa, berakhlak mulia, sehat, beriman, cakap, kreatif, mandiri, dan menjadi warga Negara yang demokratis sera tanggugjawab" untuk mencapai tujuan pendidikan, dilakukan pengembangan kurikulum pembelajaran yang digunakan dalam dunia pendidikan.

Kurikulum 2013 menuntut adanya perubahan dari proses pembelajaran yang menekankan pada peserta didik aktif untuk mencari dan menemukan sendiri kebutuhan dalam belajarnya dan pendidik berperan sebagai fasilitator untuk membimbing proses pembelajaran (Agustina, 2018).

SMP Negeri 1 Kualuh Selatan adalah salah satu sekolah yang melaksanakan proses pembelajaran menggunakan Kurikulum 2013. Kurikulum 2013 menuntut pelaksanaan pembelajaran IPA di sekolah dilakukan secara scientific untuk menumbuh kembangkan kemampuan berpikir, bekerja, bersikap ilmiah dan berkomunikasi sebagai salah satu aspek penting keterampilan hidup (Leonda dkk, 2015). Hasil observasi yang dilakukan peneliti di SMP N 1 Kualuh Selatan menunjukan bahwa pembelajaran IPA yang dilakukan guru masih menggunakan metode konvensiona yaitu ceramah yang menyebabkan pembelajaran masih berpusat pada guru dan tidak menekankan keaktifan peserta didik sehingga mempengaruhi hasil pembelajaran. Diketahu dari hasil obeservasi yang di lakukan bahwa hasil belajar peserta didik pada materi pencemaran lingkungan masih belum memenuhi Kriteria Ketuntasan Minimum (KKM) sebesar 76.

Data daftar nilai ulangan harian 30 peserta didik yang mencapai standar KKM hanya $27 \%$ perserta didik dengan nilai rata-rata 62,5 Sedangkan sisanya $73 \%$ peserta didik mendapatkan nilai <76. Rendahnya hasil belajar peserta didik dikarenakan peserta didik belum maksimal terlibat secara aktif dalam proses pembelajaran. Hal ini ditunjukkan saat mengikuti proses pembelajaran di kelas, peserta didik ada yang tidak memperhatikan saat guru menerangkan pelajaran, suka mengganggu teman, sibuk dengan kepentingannya sendiri seperti bermain hp, berbicara dengan teman sebangkunya.

Mengatasi permasalahan tersebut, diperlukan sebuah inovasi dalam menerapkan suatu model pembelajaran yang menarik dan berpusat pada siswa dengan kegiatan pembelajaran yang mengaktifkan siswa untuk mekonstruksi materi pelajaran sehingga meningkatkan hasil belajar IPA siswa. Pada kurikulum 2013 terdapat beberapa model pembelajaran yang dianjurkan oleh pemerintah untuk digunakan dalam proses belajar mengajar di sekolah, salah satunya adalah PBL dan penggunaan media pembelajaran yang dapat menarik minat belajar peserta didik (Rerung, dkk., 2017).

Problem Based Learning ( $\mathrm{PBL}$ ) adalah pembelajaran yang memiliki esensi berupa pemaparan berbagai masalah yang autentik dan bermakna kepada peserta didik sehingga dapat berfungsi sebagai sarana untuk melakukan investigasi dan penyelidikan (Arends, 2011). Menurut Utrifani dan Turnip (2014) menyatakan bahwa PBL merupakan suatu model pembelajaran yang melibatkan peserta didik untuk memecahkan suatu masalah melalui tahap metode ilmiah sehingga peserta didik dapat mempelajari pengetahuan yang berhubungan dengan masalah tersebut serta memiliki keterampilan untuk memecahkan masalah. Shoimin (2016), menyatakan bahwa PBL merupakan 
pengembangan kurikulum dan sistem pengajaran yang mengembangkan secara simultan strategi pemecahan masalah dan dasar-dasar pengetahuan dan keterampilan dengan menempatkan para peserta didik dalam peran aktif sebagai pemecah permasalahan sehari-hari yang tidak terstruktur dengan baik. PBL meruapakan model yang memprioritaskan kesesuaian belajar dengan hal-hal yang ditemukan dalam kehidupan sehari-hari peserta didik.

Hasil penelitian Afolabi, menyatakan bahwa terdapat perubahan yang signifikan terhadap hasil belajar siswa dengan menggunakan model problem based learning di bandingkan dengan model konvensional (Sani, dkk., 2016). Sejalan dengan hal tersebut Albanese dan Mitchel memperkuat bahwa dibandingkan dengan model pembelajaran konvensional, lebih baik digunakan model pembelajaran berbasis masalah yang mampu mengkonstruksi konsep dan meningkatkan hasil belajar peserta didik (Prima dan Heni, 2015).

Berdasarkan hasil observasi juga diketahui dalam pembelajaran yang dilakukan guru belum menggunakan media pembelajaran sehingga siswa tidak terlibat secara aktif dalam proses belajar mengajar. Hal ini berakibat pada tidak tertariknya siswa dengan pembelajaran yang dilakukan sehingga siswa merasa bosan dan akibatnya berdampak pada hasil belajar yang diperoleh. Berdasarkan hasil obeservasi juga diketahui sarana dan prasarana yang dimiliki sekolah tersebut cukup lengkap. SMPN 1 Kualuh Selatan sudah memiliki saran dan prasarana yang baik terutama laboratorium IPA yang representatif untuk gunakan dalam pembelajaran IPA namun tidak pergunakan oleh guru karena tidak pahamnya guru dalam penggunakan alat-alat laboratorium.

Salah satu upaya yang dapat dilakukan untuk mengatasi masalah tersebut adalah dengan menggunakan media pembelajaran dalam proses kegiatan belajar mengajar. Penggunaan model dan media pembelajaran yang dipilih guru merupakan salah satu cara meningkatkan kualitas pembelajaran. Hal ini juga seiring dengan yang dinyatakan oleh Munadi (2013) untuk meningkatkan minat belajar dan hasil belajar siswa dalam proses pembelajaran, selain dapat dilakuan dengan cara memilih model pembelajaran yang menarik juga dapat menggunakan media pembelajaran. Salah satu media pembelajaran menarik yang dapat digunakan yaitu pembelajaran berbasis teknologi berupa Power point Interaktif. Hal senada juga dinyatakan oleh Hamalik (2008) bahwa pemakaian media pembelajaran proses kegiatan belajar mengajar dapat membangkitkan keinginan dan minat yang baru serta membangkitkan motivasi dan minat belajar sehingga dapat meningkatkan hasil belajar peserta didik.

Berdasarkan uraian diatas, peneliti perlu melakukan penelitian dengan tujuan untuk mengetahui peningkatan hasil belajar IPA peserta didik SMP $\mathrm{N} 1$ Kualuh Selatan dengan menggunakan model PBL dan media pembelajaran berupa power point interaktif.

\section{METODE}

Jenis penelitian yang digunakan dalam penelitian ini adalah penelitian tindakan kelas (PTK), yang merupakan suatu kegiatan pengamatan yang dilakukan terhadap kegiatan belajar berupa sebuah tindakan yang sengaja dimunculkan yang terjadidalam sebuah kelas secara bersamaan untuk melakukan perbaikan dan pengamatan hasil belajar peserta didik kelas VII2 di SMP N 1 Kualuh Selatan yang berada di kabupaten Labuhanbatu Utara yang berjumlah 30 orang peserta didik.

Model PTK yang digunakan dalam penelitian ini merupakan model Kurt Lewin yang terdiri dari 4 tahap kegaiatan yaitu tahap perencanaan, tahap pelaksanaan, tahap pengamatan dan tahap refeksi. Penelitian terdiri dari 2 siklus yang dilakukan pada satu kelas yang sama (Kusuma, dkk., 2012). Tahap perencanaan, yaitu menentukan tujuan pembelajaran, materi pelajaran, mengembangkan bahan-bahan untuk dipelajari oleh peserta didik. Tahap pelaksaan tindakan merupakan kegiatan proses belajar mengajar dengan model PBL antara peneliti dengan peserta didik sehingga terjadi interaksi. Tahap pengamatan, yaitu kegiatan pengamatan yang dilakukan secara langsung oleh peneliti dengan menggunakan lembar pengamatan dalam pelaksanaan pembelajaran dengan model pembelajaran PBL. Refleksi, yaitu kegiatan dalam usaha perbaikan 
untuk pertemuan kegiatan selanjutnya dari evaluasi kekurangan pembelajaran sebelumnya dan menjadi titik tolak dari hasil pengamatan dan diskusi yang dilakukan oleh peneliti dengan guru observer yang membantu penelitian (Simanjuntak, dkk., 2019). Alur kegiatan yang dilakukan dalam penelitian tindakan kelas dengan model PBL dengan menggunakan media power point Interaktif ditunjukkan pada Tabel 1.

\section{Tabel 1. Alur kegiatan Penelitian Tindakan Kelas}

\begin{tabular}{|c|c|}
\hline Siklus I & Kegiatan yang dilaksanakan \\
\hline Perencanaan & $\begin{array}{l}\text { - Mempersiapkan perangkat pembelajaran seperti: RPP, LKPD dan } \\
\text { skenario pembelajaran untuk tiap siklus. RPP pertemuan pertama } \\
\text { tentang Pencemaran air dan RPP pertemuan kedua tentang } \\
\text { Pencemaran Udara } \\
\text { - } \quad \text { Membuat lembar observasi aktivitas peserta didik dan guru. } \\
\text { - } \quad \text { Menpersiapkan alat dan bahan pembelajaran. } \\
\text { - } \text { Membuat kelompok peserta didik yang berjumlah } 6 \text { kelompok. } \\
\text { - } \text { Membuat soal tes. } \\
\text { - Membuat jawaban soal tes. }\end{array}$ \\
\hline $\begin{array}{l}\text { Pelaksanaan } \\
\text { tindakan }\end{array}$ & $\begin{array}{l}\text { - } \quad \text { Pelaksanaan pembelajaran sesuai dengan RPP. } \\
\text { - } \quad \text { Melakukan pembahasan dengan peserta didik tentang materi } \\
\text { - } \quad \text { Peserta didik mengambil kesimpulan terkait hasil eksperimen yang } \\
\text { - } \quad \text { Mengakukan. } \\
\text { Mengakan evaluasi. }\end{array}$ \\
\hline Observasi & $\begin{array}{l}\text { - Observasi terhadap aktivitas guru dan peserta didik pada saat } \\
\text { pembelajaran. }\end{array}$ \\
\hline Refleksi & - Hasil dari refleksi sebagai pedoman menyusun rencana pada siklu \\
\hline
\end{tabular}

Siklus II dilaksanakan dengan melakukan perbaikan pada penyusunan RPP pada siklus kedua dengan mengoptimalkan waktu pada pembukaan, alokasi waktu pengolahan data dan presentasi yang dilakukan peserta didik. Lebih mempersiapkan alat dan bahan untuk kegiatan percobaan agar lebih efektif dan efisien.

Instrumen tes yang digunakan dalam penelitian ini berbentuk tes pilihan ganda berjumlah 30 soal dan uraian berjumlah 10 soal pada materi pencemaran lingkungan. Teknik analisis data yang digunakan dalam penelitian ini adalah Teknik deskriptif kuantitatif dan kualitatif. Data yang diperoleh dari hasil tes yang berbentuk pilihan ganda dan uraian adalah data kuantitatif. Data ini disajakan dalam bentuk angka sedangkan data kualitatif didapatkan dari hasil observasi yang berupa suatu penjelasaan atau keterangan.

\section{HASIL DAN PEMBAHASAN}

\section{Hasil}

Penelitian ini dilakukan pada tanggal tanggal 9 sampai 16 Maret 2020 di kelas VII2 SMP N 1 Kualuh Selatan, dengan jumlah peserta didik 30 orang (22 perempuan dan 8 laki-laki) pada materi Pencemaran air. Pada siklus I pembelajaran dilakukan dengan menerapkan model pembelajaran PBL dengan menampilkan masalah pencemaran air dilingkungan sekitar sekolah yang dimuat dalam 
media pembelajaran berbentuk Power Point pada materi pencemaran lingkungan. Hasil belajar peserta didik pada aspek kognitif ditunjukkan dengan nilai pre-test dan post-test yang dilakukan sebelum dan sesudah pembelajaran.

Data pre-test digunakan sebagai data kemampuan awal pengetahuan peserta didik terhadap materi pencemaran air. Data pre-test dan post-test peserta didik pada siklus 1 dapat dilihat pada Tabel 2.

Tabel 2. Data Pre-test dan Post-test Peserta didik pada Siklus I

\begin{tabular}{|c|c|c|}
\hline Jenis data yang diamati & Hasil pre-test & Hasil post-test \\
\hline Nilai tertinggi & 70,00 & 90,00 \\
\hline Nilai terendah & 0 & 50,00 \\
\hline Jumlah peserta didik yang tuntas belajar $(\geq 70)$ & 5 & 21 \\
\hline Jumlah peserta didik yang belum tuntas belajar $(<70)$ & 25 & 9 \\
\hline Rata-rata nilai & 28,10 & 74,00 \\
\hline
\end{tabular}

Berdasarkan Tabel 2, diketahui bahwa hasil rata-rata nilai pre-test peserta didik sebesar 29,10 . Jumlah peserta didik yang tuntas belajar sebanyak 6 orang dan yang belum tuntas belajar sebanyak 24 orang. Dari hasil tersebut dapat ketahui bahwa kemampuan awal peserta didik dalam pembelajaran IPA pada materi Pencemaran lingkungan rendah.

Berdasarkan Tabel 2 diketahui bahwa nilai pre-test terendah o dan nilai tertinggi 70,00 serta dengan rata-rata nilai 28,10 . Nilai post-test terendah yaitu 50,00, dan nilai tertinggi 90 dengan ratarata nilai 74,00. Pada siklus 1 ini dari 30 peserta didik, jumlah peserta didik yang tuntas belajar sebanyak 21 orang dan peserta didik yang tidak tuntas sebanyak 9 orang. Ketuntasan belajar peserta didik dalam materi kalor sebesar $67 \%$ yang memperoleh nilai di atas KKM yang ditetapkan sekolah, yaitu lebih besar dari 70.

Hasil pengamatan yang dilakukan pada saat siklus I menunjukkan bahwa peserta didik belum mampu untuk berkonsentrasi dengan proses pembelajaran yang berlangsung karena guru yang biasanya pengajar hanya satu orang menjadi tiga orang sehingga perhatian peserta didik lebih tertuang kepada guru. Selain itu banyak dari peserta didik bingung melakukan kegiatan seperti yang terdapat di dalam LKPD karena mereka jarang menggunakan LKPD, terdapat beberapa peserta didik yang lebih cepat menanggapi arahan dari guru yaitu merumuskan masalah namun sebagian besar peserta didik belum dapat merumuskan masalah serta belum aktif berdiskusi dengan kelompok yang telah di bentuk. Hal ini menyebabkan hasil belajar yang di dapatkan peserta didik rendah yang dilihat dari hasil post-test peserta didik.

Siklus II penelitian ini dilakukan berdasarkan hasil belajar peserta didik pada siklus I, karena ketuntasan belajar peserta didik belum memenuhi $80 \%$ sehingga dilakukanya pembelajaran pada siklus II. Siklus kedua mengkaji tentang Pencemaran udara. Setelah dilakukan pembelajaran siklus II selama 2 jam pelajaran dengan menerapkan model PBL dan menggunakan media power point interaktif diperoleh hasil pre-test dan post-test peserta didik seperti pada Tabel 3. 
Tabel 3. Data Pre-test dan Post-test Peserta didik pada Siklus II

\begin{tabular}{lll}
\hline \multicolumn{1}{c}{ Jenis data yang diamati } & \multicolumn{1}{c}{ Hasil pre-test } & Hasil post-test \\
\hline Nilai tertinggi & 71,00 & 93,00 \\
Nilai terendah & 0 & 60,00 \\
Jumlah peserta didik yang tuntas belajar $(\geq 70)$ & 6 & 27 \\
Jumlah peserta didik yang belum tuntas belajar $(<70)$ & 24 & 3 \\
Rata-rata nilai & 42,00 & 89,30 \\
\hline
\end{tabular}

Berdasarkan Tabel 3, diketahui bahwa hasil rata-rata nilai pre-test peserta didik sebesar 42,00. Jumlah peserta didik yang tuntas belajar sebanyak 6 orang dan yang belum tuntas belajar sebanyak 24 orang. Dari hasil tersebut dapat ketahui bahwa kemampuan awal peserta didik dalam pembelajaran IPA pada materi perpindahan kalor rendah.

Berdasarkan Tabel 3 diketahui bahwa nilai pre-test terendah o dan nilai tertinggi 71,00 serta dengan rata-rata nilai 42,00. Nilai post-test terendah 60,00 dan nilai tertinggi 93,00 dengan ratarata nilai 89,30 . Pada siklus II ini, dari 30 peserta didik, jumlah peserta didik yang tuntas belajar sebanyak 27 orang dan peserta didik yang belum tuntas belajar sebanyak 3 orang. Ketuntasan belajar peserta didik dalam materi pencemaran lingkungan sebesar $86,7 \%$ yang memperoleh nilai di atas KKM yang ditetapkan sekolah, yaitu lebih besar dari 70.

Hasil pengamatan yang dilakukan pada saat siklus II menunjukkan bahwa peserta sudah mampu berkonsentari dengan PTT interaktif yang di tampikan sehingga peserta didik lebih dapat menyerap informasi yang ingin di sampaikan oleh guru. Selain itu peserta didik sudah mampu mengerjakan LKPD yang di berikan oleh guru sesuai dengan kegiatan yang tertera dalam LKPD tersebut. Pada siklus II peserta didik aktif dalam memberikan pendapat pada saat diskusi kelompok dan berperan aktif dalam proses pembelajaran sehingga hasil belajar yang di dapat meninggat dari siklus I.

Hasil perhitungan yang telah dilakukan untuk rata-rata nilai siswa dan persentase peningkatan $\mathrm{N}$-Gain hasil belajar dari dua siklus ditunjukkan pada Tabel 4. Tabel 4. Hasil perhitungan rara-rata Nilai Pre-test dan Post-test dan Persentase peningkatan N-Gain untuk 2 Siklus.

Tabel 4. Rata-rata Nilai Pre-test dan Post-test dan \% N-Gain Peningkatan Hasil Belajar

\begin{tabular}{rrrr}
\hline Siklus & Pre-test & Post-test & N-Gain (\%) \\
\hline I & 28,10 & 74,00 & 63,8 \\
\hline II & 42,00 & 89,30 & 81,2 \\
\hline
\end{tabular}

Berdasarkan Tabel 4 diketahui bahwa hasil perhitungan untuk rata-rata nilai siswa dan persentase peningkatan $\mathrm{N}$-Gain hasil belajar dari dua siklus menunjukkan siklus II lebih tinggi dari siklus I. Persentase peningkatan hasil belajar pada siklus I sebesar 63,8\% pada kategori sedang dan pada siklus II yaitu $81,2 \%$ pada kategori tinggi. Dapat di simpulkan bahwa terdapat peningkatan hasil belajar peserta didik dengan menggunakan model PBL dan menggunakan media Power point interaktif pada materi Pencemaran lingkungan pada mata pelajaran IPA di SMP N 1 Kualuh Selatan.

\section{Pembahasan}

\section{a.) Siklus I}

Siklus I terdapat empat tahapan kegiatan yang dilakukan yaitu perencanaan, pelaksanaan tindakan, observasi dan refleksi. Tahap perencanaan kegiatan yang dilakukan yaitu mempersiapkan 
perangkat pembelajaran seperti: RPP, LKPD dan skenario pembelajaran untuk setiap siklus. Membuat lembar observasi aktivitas peserta didik dan guru, mempersiapkan media power point interaktif serta alat dan bahan pembelajaran. Membuat kelompok peserta didik yang berjumlah 6 kelompok, dan membuat soal tes dan jawaban dari soal tes tersebut.

Tahapan pelaksanaan tindakan kegiatan yang dilakukan, yaitu mengaplikasikan kegiatan yang tertuang didalam RPP dimulai dari kegiatan pendahuluan, kegiatan inti dan kegiatan penutup. Kegiatan pendahuluan, pada kegiatan ini, peneliti membuka kegiatan pembelajaran dengan menyampaikan salam, mengabsen peserta didik yang hadir dalam kegiatan pembelajaran, kemudian menyampaikan kompetensi yang harus di capai peserta didik setelah pembelajaran berakhir dan melakukan apersepsi dengan menampilkan video animasi didalam power point interaktif yang kemudian diikuti oleh pemaparan keadaan lingkungan sekitar dan mengaitkan dengan materi yang akan dipelajari sehingga didik tertarik dan tertantang untuk belajar IPA pada materi pencemaran lingkungan.

Kegiatan inti, peneliti memulai materi pembelajaran dengan mengarahkan peserta didik untuk memahami permasalahan tentang pencemaran air melalui media pembelajaran power point interaktif dan kemudian meminta peserta didik untuk melakukan penyelidikan cara mengatasi masalah tersebut dengan cara melakukan praktikum sederhana. Kegiatan praktikum yang dilakukan peserta didik tertuang dalam LKPD yang diberikan oleh peneliti. Melalui diskusi kelompok peserta didik diberikan kesempatan untuk menganalisis hasil pemecahan masalah yang diperoleh melalui eksperimen dan menjawab pertanyaan yang ada didalam LKPD. Selanjutnya peserta didik diberikan kesempatan untuk memverifikasi hasil temuan yang diperoleh dengan berbagai sumber referensi yang relevan tentang pencemaran air dan mempresentasikan hasil kerja didepan kelas. Setelah peserta didik selesai melakukan presentasi, peneliti menutup pembelajaran dengan meluruskan konsep dari materi yang disampaikan peserta didik sebagai kesimpulan dari materi yang sudah di pelajari.

Kegiatan penutup, proses pembelajaran pada kegiatan penutup, peneliti memberikan soal berbentuk pilihan ganda dan uraian sebanyak 15 pilihan ganda dan 5 soal uraian pada materi kalor.

\section{b.) Siklus II}

Tahap perencanaan berdasarkan hasil refleksi pada siklus I maka penulis melakukan perbaikan pada penyusunan RPP pada siklus kedua dengan mengoptimalkan waktu pada pembukaan, alokasi waktu pengolahan data dan presentasi yang dilakukan peserta didik. Selain itu, peneliti lebih mempersiapkan alat dan bahan untuk kegiatan percobaan agar lebih efektif dan efisien.

Tahap pelaksanaan tindakan dilakukan dengan: kegiatan pendahuluan, inti dan penutup. Kegiatan pendahuluan pada siklus II tidak terlalu jauh berbeda dengan kegiatan pada siklus I. Terdapat perubahan waktu pada kegiatan pendahuluan yang pada awalnya 15 menit menjadi 8 untuk mengefisienkan waktu.

Kegiatan inti, peneliti memulai materi pembelajaran dengan mengarahkan peserta didik untuk memahami materi pencemaran udara melalui media pembelajaran power point interaktif, meminta peserta didik untuk menganalisis masalah dan kemudian melakukan penyelidikan dengan cara melakukan praktikum sederhana.

Kegiatan praktikum yang dilakukan peserta didik tertuang dalam LKPD yang diberikan oleh peneliti. Kegiatan selanjutnya, peserta didik diberikan kesempatan untuk mendiskusikan hasil percobaan dengan teman sekelompoknya dan memverifikasi data melalui berbagai sumber dan mempresentasikannya didepan kelas. Peneliti menutup pembelajaran dengan meluruskan konsep dari materi yang disampaikan peserta didik sebagai kesimpulan. 
Kegiatan penutup, proses pembelajaran pada kegiatan penutup, peneliti memberikan soal berbentuk pilihan ganda dan uraian sebanyak 15 pilihan ganda dan 5 soal uraian pada pencemaran lingkungan.

Berdasarkan uraian diatas dapat di ketahui bahwa dengan menerapkan model PBL dan penggunaan media pembelajaran berupa power point interaktif dapat meningkatkan daya tarik dan minat belajar peserta didik untuk belajar IPA sehingga dapat meningakatkan hasil belajar peserta didik pada materi pencemaran lingkungan. Penggunakan power point interaktif dalam kegiatan belajar mengajar membuat peserta diidk tertarik dan dapat berkonsentrasi lebih lama sehingga mampu menyerap informasi yang ingin disampaikan oleh guru sehingga dapat meningkatkan hasil belajar. Hal ini di perkuat dengan hasil penelitian Musfiqon (2012) yang mengemukakan bahwa pembelajaran yang menggunakan multimedia telah terbukti lebih efektif dan efisien serta dapat meningkatkan hasil belajar peserta didik. Media Power Point interaktif termasuk dalam multimedia yaitu jenis media yang selain mengandung unsur suara dan gambar yang dapat dilihat. Hal ini dapat memudahkan peserta didik untuk memahami materi yang abstrak menjadi nyata. Penggunaan Power Point interaktif dapat meningkatkan hasil belajar karena media ini mampu memaparkan materi yang rumit dengan cara yang sederhana, sesuai dengan tingkat berpikir peserta didik.

Sejalan dengan hal tersebut Ahyar, dkk (2014) menyetakan bahwa multimedia memiliki kelebihan yaitu mampu membantu peserta didik menggambarkan sesuatu yang bersifat rumit karena media ini dilengkapi dengan gambar, foto, bagan, skema, animasi, video dan lain-lain. Materi yang rumit juga dapat dijelaskan dengan cara yang sederhana, sesuai dengan tingkat berpikir peserta didik, disertai dengan percobaan- percobaan sederhana yang bisa dilakukan sendiri oleh peserta didik, sehingga lebih mudah dipahami. Sejalan dengan hal tersebut Grzeszczyk (2016) menyatakan bahwa Power Point sebuah program yang memungkinkan Adanya interaksi antara media dengan pengguna dan memungkinkan untuk menciptakan berbagai aktivitas, mulai dari Pembelajaran yang interaktif, kuis interaktif dan bahkan permainan. Power Point dapat digunakan dalam sebuah presentasi, namun program ini juga memiliki fasilitas untuk membuat multimedia pembelajaran interaktif. Hal ini sesuai dengan pendapat Darmawan (2012) beberapa versi Power Point sudah memiliki fitur-fitur yang semakin lengkap sehingga sangat cocok dikembangkan menjadi multimedia interakti

Pembelajaran yang berpusat pada peserta didik diharapkan dapat meningkatkan keaktifan dan tanggungjawab serta inisiatif untuk mengenali kebutuhan belajarnya. Hal ini didukung oleh Cahyaningsih, dkk., (2020) yang menumukan bahwa penerapan model pembelajaran PBL dengan menggunakan media media pembelajaran power point interaktif dapat meningkatkan aktivitas belajar dan hasil belajar peserta didik kelas V SD Negeri 1 Pasar Banggi Rembang.

Penerapan model PBL membuat peserta didik aktif dalam belajar dan termotivasi karena dalam prosesnya peserta didik dituntun untuk dapat membangun sendiri pengetahuan dalam bentuk konsep sehingga dapat menyelesaikan permasalahan yang terdapat dalam kehidupan sehari-hari. Hal ini juga seiring dengan penggunaan media belajar berbasis power point interaktif yang dapat menarik minat peserta didik dalam belajar karena peserta didik disuguhkan dengan fenomena nyata yang terjadi dikehidupan sehari-hari dan dikemas menarik sehingga peserta didik takut untuk melewatkan apa yang tersaji didalam power point tersebut. Hal ini didukung oleh Ramayani, (2019) yang menyatakan penggunakan media power point interaktif dan model PBL secara signifikan dapat meningaktkan hasil belajar peserta didik (Busra, 2015).

\section{KESIMPULAN}

Berdasarkan hasil penelitian diperoleh kesimpulan bahwa adanya peningkatan hasil belajar peserta didik dengan menerapkan model PBL dan menggunakan media pembelajaran Power point interaktif pada materi pencemaran lingkungan pada mata pelajaran IPA di SMP N 1 Kualuh Selatan. 
Nilai rata-rata pre-test siklus I: 28,10 dan siklus II: 42,00. Nilai rata-rata post-test siklus I: 74,00 dan siklus II: 89,30. Peningkatan presentasi N-Gain pada siklus I: 63,8\% (kategori sedang) dan siklus II: $81,2 \%$ (kategori tinggi).

\section{DAFTAR PUSTAKA}

Ahyar, R., Lufri dan Sumarmin, R. (2014). Pengembangan Multimedia Pada Materi Struktur Dan Fungsi Organ Manusia Untuk Siswa Kelas Xi Sekolah Menengah Atas. Jurnal Biologi Education. Vol. 1, No.1.

Agustina, L. (2018). Efektivitas Penerapan Model Pembelajaran Dalam Kurikulum 2013 Di SMP Negeri 1 Delanggu. Jurnal Pelita Pendidikan. Vol 15 No.1.

Arends, R. I. (2011). Learning to Teach, (terjemahan). Yogyakarta: Pustaka Pelajar

Busra, K.H, Festiyed, dan Ramli. (2015). Analisis Kebutuhan Pengembangan Media Pembelajaran Interaktif dengan Menggunakan Power Point Berbasis Model PBL (Problem Based Learning) untuk Meningkatkan Kemampuan Berpikir. Prosiding Seminar Nasional Pembelajaran Fisika II. Universitas Negeri Padang.

Cahyaningsih, P., Siswanto, J., dan Sukamto. (2020). Keefektifan Model Project Based Learning Berbantu Multimedia Power Point Terhadap Hasil Belajar IPA. Jurnal Penelitian dan Pengembangan Pendidikan. Vol. 4. No. 1.

Darmawan. (2012). Teknologi Pembelajaran. Bandung: PT Remaja Rosdakarya

Dimyati dan Mudjiono. (2006). Belajar dan Pembelajaran. Jakarta: PT Rineke Cipta

Grzeszczyk, K. B. 2016. Tools Used In Computer Assisted Language Learning And Multimedia In The Classroom. Journal of World Scentific News, WSN. Vol 43. No. 3.

Hamalik, O. (2008). Proses Belajar Mengajar. Jakarta: Bumi Aksara

Kusuma, W dan Dwitagama, D. (2012). Mengenal Penelitian Tindakan Kelas. Jakarta: Indeks

Leonda, M.A., Desnita, dan Agus (2015). Pengembangan Modul Berbasis Problem base Learning untuk Materi Usaha dan Energi di SMA. Prosiding Seminar Nasional Fisika, 5.

Munadi, Y. (2013). Media Pembelajaran: Sebuah Pendekatan Baru. Jakarta: Referensi

Musfiqon. (2012). Pengembangan Media \& Sumber Pembelajaran. Jakarta: Prestasi Pustaka Raya.

Nisa, A. K. (2015). Implementasi Model Pembelajaran Problem Based Learning untuk Meningkatkan Keaktifan dan Hasil Belajar Siswa pada Mata Pelajaran Pemrograman Desktop Kelas XI RPL SMK Ma'arif Wonosari (Skripsi). Universitas Negeri Yogyakarta.

Rerung, N., Iriwi, dan Widyaningsih, S. (2017). Penerapan Model Pembelajaran Problem Based Learning (PBL) Untuk Meningkatkan Hasil Belajar Peserta Didik SMA Pada Materi Usaha Dan Energi. Jurnal Ilmiah Pendidikan Fisika Al-BiRuNi.Vol 6. No. 1.

Prima. C., \& Heni, R.,(2015), Penerapan Model Pembelajaran Problem Based Learning Dengan Pendekatan Inkuiri Untuk Meningkatkan Keterampilan Proses Sains Dan Penguasaan Konsep Elastisitas Pada Siswa. Jurnal Pendidikan IPA, vol 16. No 1.

Sani. A., Rizka \& Sahyar. (2016), Analisis Perangkat Pembelajaran Fisika Berbasis Model Problem Based Learning. Jurnal Pendidikan Fisika, vol 5. No 2.

Shoimin, A. 2016. Model Pembelajaran Inovatif dalam Kurikulum 2013. Yogyakarta: Ar-Ruzz Media

Simanjuntak, M. P., Siregar, L., dan Lumbangaol, Y. T. (2019). Penerapan Discovery Learning terhadap Hasil Belajar IPA Peserta Didik SMP. Jurnal Inovasi Pembelajaran Fisika. Vol 7 No. 4.

Utrifani, A., dan Turnip, B.M. (2014). Pengaruh Model Pembelajaran Problem Based Larning terhadap Hasil Belajar Siswa pada Materi Pokok Kinematika Gerak Lurus Kelas X SMA Negeri 14 Medan T.P.2013/2014. Jurnal Inpafi. Vol 2. No. 2. 


\section{Nanda Alwardah}

Mahasiswa Pendidikan IPA, Universitas Negeri Medan, nandaalwaardah@gmail.com.

\section{Kardinal Sitorus}

Mahasiswa Pendidikan IPA, Universitas Negeri Medan, Kardinalsitorus123@gmail.com.

\section{Nuraini}

Guru SMP Negeri 1 Kualuh Selatan, anur72492@gamial.com. 